\title{
Hubungan pola komunikasi orangtua terhadap perkembangan berbicara anak di taman kanak-kanak
}

\author{
Triwidya Astuti ${ }^{1}$, Nurhafizah ${ }^{2}$, Yulsyofriend ${ }^{3}$ \\ Universitas Negeri Padang \\ Email : triwidya956@gmail.com
}

\begin{abstract}
The purpose of this study was to look at the relationship between parental communication patterns on children's speaking development in kindergarten in Koto Tangah sub-district, Padang city. This type of research is correlational research with quantitative methods. The population in this study were kindergartens in the Koto Tangah sub-district. Samples taken using a simple random sampling technique are children and parents who are in kindergarten - Koto Tangah Padang sub-district Based on data analysis, the coefficient of determination between parental communication patterns and children's speech development is 0.294 and the correlation coefficient is 0.434. The result is that the parent communication pattern is $43.4 \%$ of the child's speaking development is significant at the 5\% level. It can be concluded that the pattern of parental communication has a significant relationship to the development of speaking of children in kindergarten in Koto Tangah sub-district, Padang City, at $43.4 \%$.
\end{abstract}

Keywords: parent communication pattern, child speaking development

\section{PENDAHULUAN}

Anak usia dini adalah anak yang berada pada rentan usia 0-6 tahun, pada masa ini perkembangan kecerdasan anak meningkat dari 50\% menjadi $80 \%$. Sedemikian pentingnya masa ini sehingga usia dini disebut sebagai golden age (usia emas). Masa ini merupakan masa yang tepat untuk mengembangkan berbagai potensi yang dimiliki anak. Potensi tersebut akan dapat berkembang jika diberi rangsangan, bimbingan, bantuan, dan perlakuan yang sesuai dengan tingkat pertumbuhan dan perkembangannya. Nurhafizah (2015) menyatakan bahwa proses pembelajaran sangat perlu dilakukan sejak dini.

Pendidikan anak sejak dini sangan mempengauhi perkembangan anak (Nurhafizah, 2017). Pendidikan pada anak diawali didalam keluarga semenjak seorang anak dilahirkan (Nurhafizah, 2018). Seorang anak mulai berkomunikasi dengan orang terdekatnya seperti ibu, ayah, dan anggota keluarga terdekat lainnya. Orangtua yang paling peka memahami bahasa anak adalah Ibu. Kepekaan ibu muncul pada saat menyusui anak dan menidurkan anaknya. Pada saat inilah bunyi-bunyi bahasa di hasilkan dan diwujudkan dalam kalimat satu kata, dua kata, atau 
lebih dari tiga kata. Komunikasi yang dibangun orangtua sangat mendukung perkembangan berbicara anak (Djamarah : 2014).

Berdasarkan teori Behaviorisme lingkungan memiliki peranan yang kuat dalam mempengaruhi perkembangan anak. Lingkungan merupakan salah satu faktor yang tidak dapat dipisahkan dari kehidupan anak karena anak tumbuh dan berkembang oleh pengaruh lingkungan, mulai dari lingkungan yang informal, formal dan non formal. Di dalam lingkungan terdapat lingkungan keluarga dan lingkungan sekolah. Orangtua menjadi penanggung jawab terhadap kelangsungan kehidupan anak dirumah, dan kehidupan dirumah harus dibentuk menjadi lingkungan yang akan memberikan pelayanan terhadap tumbuh kembang anak ke arah positif sehingga harus teratur dan terprogram (Nurhafizah, 2014). Walaupun di rumah aturan harus ada, dan ketegasan dalam menegakan aturan itu tidak identik dengan keras atau bentakan tapi ketegasan adalah ketika anak melakukan kebaikan anak harus dihargai dengan memberikan reward, jika melakukan pelanggaran anak harus diberikan sangsi. Sangsi harus ada kesepakatan antara anak dan orangtua, sangsi tidak boleh berupa hukuman fisik, cacian, dan makian, tapi harus bersifat mendidik (Suryana: 2013).

Komunikasi yang baik merupakan dasar bagi seorang anak dapat berbicara dengan efektif. Dalam kesempatan belajar keefektifan komunikasi orangtua dengan anak sangat berpengaruh terhadap kepribadianya. Karena kesibukan orangtua sehingga kurangnya komunikasi antara orangtua dan anak (Nurhafizah, 2012). Kurangnya komunikasi orangtua terhadap anak juga dapat menghambat perkembangan berbicara pada anak, maksudnya disini yaitu orangtua yang terlalu sibuk bekerja dan tidak mempunyai waktu untuk berkomunikasi terhadap anaknya, kita contohkan saja ketika anak menonton televisi anak harus dibimbing oleh orangtua, karena anak akan belajar bahasa baru pada setiap tayangan yang ditontonnya dan anak akan bertanya tentang kata-kata yang baru didengarnya, jika orangtua tidak memperhatikan hal tersebut maka akan menyebabkan terlambatnya anak dalam berbicara karena anak tidak mampu untuk mengeluarkan kata-kata yang ia tidak mengerti (Nurhafizah, N, 2018).

Hubungan orangtua dan anak, terutama komunikasi sangat penting untuk menstimulasi anak agar memperbanyak kosa katanya. Akan tetapi sebagian besar orangtua tidak menyadari bahwa komunikasi atau dialog antara anak dengan orangtua sangat berpengaruh terhadap perkembangan anak, baik itu dari sisi kemampuan berbicara maupun secara psikologi anak. Pada era globalisasi saat ini banyak ditemukan bahasa anak yang tidak pantas di ucapkan oleh anak usia dini pada umumnya. Misalkan anak usia dini saat sekarang ini sering mengucapkan kata-kata kotor bahkan sudah bisa membantah perkataan orangtuanya, berbicara yang tidak sopan dengan orang yang lebih besar dari nya. Menurut Djamarah (2014). "Kemampuan anak mengucapkan kata-kata merupakan hasil belajar melalui imitasi (peniruan) terhadap suara-suara yang didengar anak dari orang lain (terutama orangtuanya)". Oleh karena itu orangtua menjadi sosok yang ditiru oleh anak dalam berbicara dan berkomunikasi.

Berdasarkan penelitian yang peneliti lakukan di Taman Kanak-kanak Kecamatan Koto Tangah Padang tentang hubungan pola komunikasi orangtua terhadap perkembangan berbicara anak. Diperoleh hasil penelitian bahwa antara pola komunikasi orangtua terhadap perkembangan berbicara anak memiliki hubungan satu sama lain, yang berarti bagaimana orangtua berkomunikasi mempunyai hubungan yang signifikan terhadap perkembangan berbicara anak. Kemudian tujuan dari penelitian ini adalah untuk mengetahui hubungan antara pola komunikasi orangtua terhadap perkembangan berbicara anak di Taman Kanak-kanak Kecamatan Koto Tangah Padang.

Perkembangan berbicara anak dapat dikembangkan pertama kali oleh hubungan antara anak dan orangtuanya. Ferliana \& Agustina (2015) memaparkan bahwa "Cara orangtua berbicara dan mendengarkan ketika anak-anak bercerita, akan sangat memengaruhi cara anak berkomunikasi dengan orang lain". Hal ini sejalan dengan pendapat Harris dalam Otto (2015) yang mengatakan bahwa dalam berkomunikasi anak didorong untuk meniru ucapan orang lain. Sehingga dapat diartikan bahwa hubungan antara orangtua dan anak, terutama komunikasi sangatlah penting untuk menstimulasi anak agar memperbanyak kosa katanya. Ketika anak berusia enam tahun, anak sudah memahami bagaimana dan kapan berbicara menggunakan bahasa yang sopan, dan mampu menceritakan peristiwa dengan alur yang tepat. 


\section{METODE PENELITIAN}

Penelitian ini adala jenis penelitian ini yaitu jenis penelitian korelasional dengan metode kuantitatif. Populasi dalam penelitian ini adalah anak dan orangtua di Taman Kanak - kanak Darul Falah, Taman Kanak - kanak Nur illahi dan Taman Kanak - kanak Islam Kurnia Asy Syifa Kecamatan Koto Tangah Padang.Sampel yang di ambil menggunakan teknik simple random sampling yaitu mengambil sampel secara acaktanpa memperhatikan strata yang ada dalam populasi yaitu 15 orangtua anak dan 15 orang anak yang berusia 5 sampai 6 tahun di Taman Kanak kanak Darul Falah Kecamatan Koto Tangah, Taman Kanak - kanak Nur Illahi Kecamatan Koto Tangah dan Taman Kanak - kanak Islam Kurnia Asy syifa Kecamatan Koto Tangah, sehingga berjumlah 45 orang anak dan 45 orang tua, atau 90 orang.Instrumen ini menggunakan skalalikert, butir pernyataan untuk tingkat pemahaman model skala likertnya yaitu: Selalu (SL) diberi bobot 5, Sering (SR) diberi bobot 4, Kadang-kadang (KK) diberi bobot 3, Jarang (JR) diberi bobot 2, dan Tidak Pernah (TP) diberi bobot 1, untuk pernyataan positif. Sedangkan untuk pernyataan negatif, Selalu (SL) diberi bobot 1, Sering (SR) diberi bobot 2, Kadang-kadang (KK) diberi bobot 3, Jarang (JR) diberi bobot 4, dan Tidak Pernah (TP) diberi bobot 5 .

Penelitian ini dilakukan dengan teknik penyebaran angket kepada seluruh responden yang telah ditetapkan yaitu orangtua dan guru dari anak di Taman Kanak - kanak Darul Falah Kecamatan Koto Tangah, Taman Kanak kanak Nur Illahi Kecamatan Koto Tangah dan Taman Kanak - kanak Islam Kurnia Asy syifa Kecamatan Koto Tangah. Sebelum menyebarkan angket kepada responden di tempat penelitian terlebih dahulu peneliti melakukan uji coba instrumen di tempat validasi yaitu di Taman Kanak-kanak Islam Shabrina Nanggalo Padang. Setelah melakukan uji coba instrument semua item pernyataan dari variabel $\mathrm{X}$ dan variabel $\mathrm{Y}$ valid.

Reliabilitas bertujuan untuk mengetahui apakah keadaan instrumen yang digunakan memiliki ketetapan yang sama dalam mengukur, artinya instrumen yang bila digunakan beberapa kali untuk mengukur obyek yang sama akan menghasilkan data yang sama. Untuk menentukan reliabilitas angket digunakan rumus Alpha Cronbach yang dikemukakan Arikunto (2014: 221), dengan bantuan program SSPS versi 20. Teknik analisis data yang digunakan dalam penelitian adalah melakukan pemeriksaan terhadap angket yang telah diberikan kepada responden, menganalisis angket sesuai dengan indikator yang telah diberikan, jawaban tiap kisi tersebut diberi skor yaitu menggunakan skala likert.Uji normalitas bertujuan untuk mengetahui normalitas kedua variabel penelitian. Untuk itu uji normalitas dilakukan menggunakan rumus Kolmogrov-Smirnov, dilakukan dengan bantuan program SPSS versi 20. Kaidah yang digunakan untuk mengetahui normalitas sebaran data adalah jika p $>0.05$ sebaran dikatakan normal, atau jika $\mathrm{p}<0.05$ maka sebaran di anggap tidak normal.

Uji hipotesis penelitian diarahkan untuk menguji hipotesis dalam penelitian ini hipotetis dalam penelitian ini berbunyi " terdapat hubungan yang signifikan antara pola komunikasi orangtua terhadap perkembangan berbicara anak di Taman Kanak - kanak Kecamatan koto Tangah Padang”. Uji hipotesis ini menggunakan teknik analisis product moment yang di analisis menggunakan program SPSS versi 20

\section{HASIL PENELITIAN}

Data pola komunikasi orangtua $(\mathrm{X})$ dikumpulkan melalui angket yang terdiri dari 15 butir pernyataan yang telah diuji validitas dan reliabilitasnya. Selanjutnya angket disebarkan kepada 45 orangtua sebagai responden untuk diisi. Dari data penelitian diketahui bahwa distribusi skor jawaban menyebar dari skor terendah 24 dan tertinggi 72.

Data perkembangan berbicara anak (Y) dikumpulkan melalui angket yang terdiri dari 10 butir pernyataan yang telah diuji validitas dan reliabilitasnya. Selanjutnya angket disebarkan kepada guru sebagai responden untuk diisi. Dari data penelitian diketahui bahwa distribusi skor jawaban menyebar dari skor terendah 12 dan tertinggi 36

Pada analisis data menerangkan bahwa nilai signifikansi probabilitas variabel X sebesar 0,910 dan variabel Y sebesar 0,882 yang lebih besar dari signifikansi $\alpha$ 0,05. Berdasarkan landasan pengambilan keputusan di atas, Ha diterima dan $\mathrm{HO}$ ditolak, dengan demikian dapat diambil kesimpulan bahwa data kedua variabel dalam penelitian ini membentuk distribusi normal. 


\section{One-Sample Kolmogorov-Smirnov Test}

\begin{tabular}{llrr}
\hline & One-Sample Kolmogorov-Smirnov Test & \\
\hline & & $\begin{array}{c}\text { pola komunikasi } \\
\text { orangtua }\end{array}$ & \multicolumn{2}{c}{$\begin{array}{c}\text { perkembangan } \\
\text { berbicara anak }\end{array}$} \\
$\mathbf{N}$ & & 45 & 45 \\
Normal Parameters ${ }^{\text {a,b }}$ & Mean & 45.13 & 24.56 \\
& Std. Deviation & 11.640 & 5.566 \\
Most Extreme Differences & Absolute & .084 & .087 \\
& Positive & .084 & .082 \\
Kolmogorov-Smirnov Z & Negative & -.069 & -.087 \\
Asymp. Sig. (2-tailed) & & .562 & .586 \\
a. Test distribution is Normal. & & .910 & .882 \\
b. Calculated from data. & & & .82 \\
\hline
\end{tabular}

Pada analisis data uji linearitas, berdasarkan pengujian yang di lakukan diperoleh Fhitung $=9.983>$ Ftabel $=$ 4,08 angka Ftabel diperoleh dari df 1.43 dan melihatnya pada tabel distribusi F0.05 Degress of freedom for Nominator, maka diperoleh Ftabel $=4,08$. Probabilitas yang di dapat $0,003<0.05$. Maka dapat disimpulkan bahwa antara pola komunikasi orangtua terhadap perkembangan berbicara anak memiliki hubungan yang linear.

\begin{tabular}{|c|c|c|c|c|c|c|}
\hline \multicolumn{7}{|c|}{ UJI F } \\
\hline Model & & Sum of Squares & Df & Mean Square & $\mathrm{F}$ & Sig. \\
\hline \multirow[t]{3}{*}{1} & Regression & 256.826 & 1 & 256.826 & 9.983 & $.003^{\mathrm{b}}$ \\
\hline & Residual & 1106.285 & 43 & 25.728 & & \\
\hline & Total & 1363.111 & 44 & & & \\
\hline \multicolumn{7}{|c|}{ a. Dependent Variable: Perkembangan Berbicara Anak (y) } \\
\hline \multicolumn{7}{|c|}{ b. Predictors: (Constant), Pola Komunikasi Orangtua (x) } \\
\hline
\end{tabular}

Berdasarkan uji $\mathrm{F}$ yang dilakukan nilai signifikansi yang diperoleh setelah menganalisis dengan menggunakan SPSS 20 adalah $0,003<0,05$. Maka dapat disimpulkan bahwa antara pola komunikasi orangtua dengan perkembangan berbicara anak memiliki hubungan.

Hipotesis yang diajukan adalah "terdapatnya hubungan yang signifikan antara pola komunikasi orangtua terhadap perkembangan berbicara anak di Taman Kanak-kanak Kecamatan Koto Tangah Padang”. Dari hasil perhitungan diperoleh koefisien korelasi X terhadap Y sebesar 0,434. Hasil perhitungan menunjukkan bahwa koefisien korelasi antara pola komunikasi orangtua dengan perkembangan berbicara anak di Taman Kanak-kanak Kecamatan Koto Tangah Padang sebesar 0,434. dengan $\rho(\mathrm{sig})=0,003<\alpha=0,05$. Ini berarti bahwa terdapat hubungan yang signifikan antara pola komunikasi orangtua terhadap perkembangan berbicara anak di Taman Kanak-kanak Kecamatan Koto Tangah Padang. Besarnya korelasi adalah 0,434 atau 43,4\%. Ini berarti bahwa terdapat hubungan pola komunikasi orangtua terhadap perkembangan berbicara anak di Taman Kanak-kanak Kecamatan Koto Tangah Padang sebesar 0,434 atau 43,4\%.

Berdasarkan perhitungan di atas diketahui harga thitung sebesar 0,434 untuk $\alpha 0,05$ dan df 44 didapat ttabel 0,408. Kemudian thitung yang diperoleh dikonsultasikan dengan ttabel, terlihat thitung > ttabel. Hal ini menunjukkan adanya hubungan positif antara pola komunikasi orangtua terhadap perkembangan berbicara anak. 


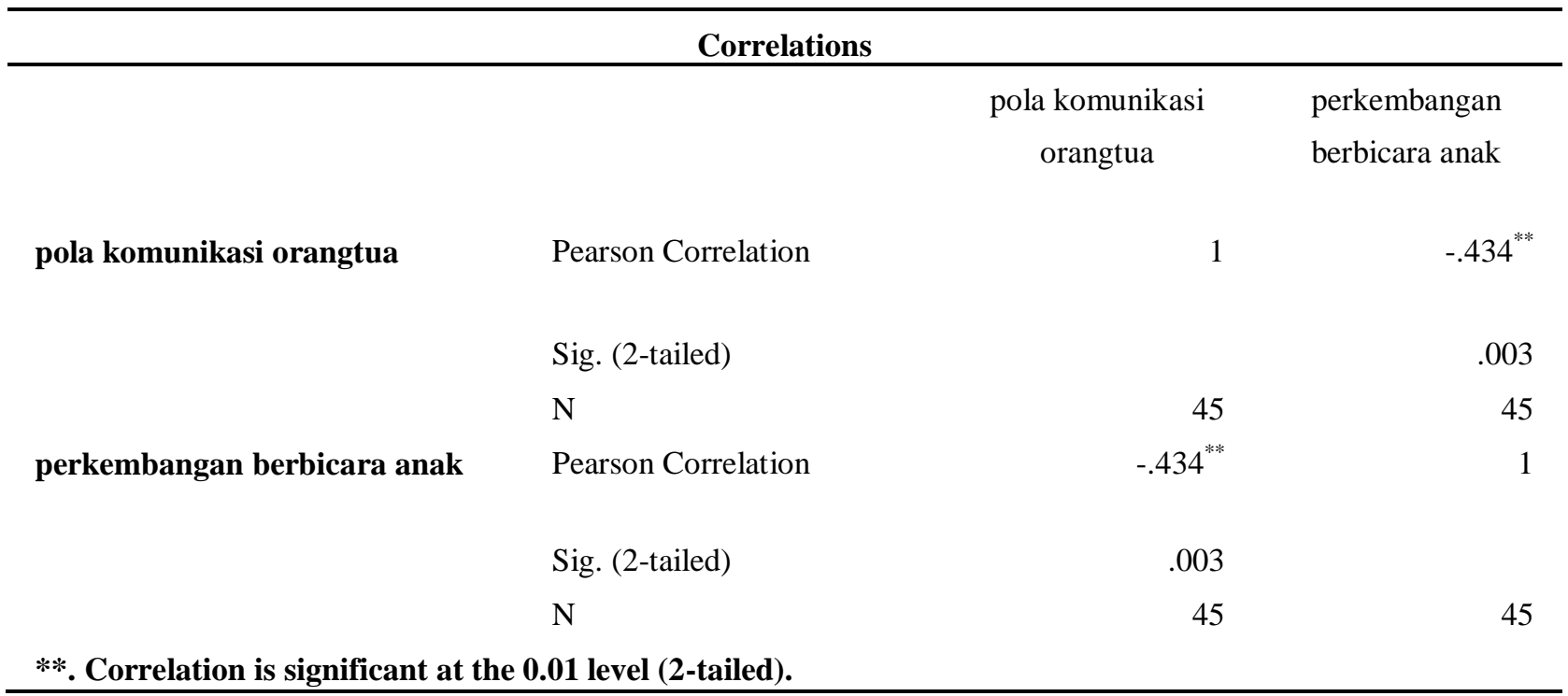

\section{PEMBAHASAN}

Dalam penelitian ini telah diperoleh gambaran tentang hubungan Pola Komunikasi Orangtua terhadap Perkembangan Berbicara Anak di Taman Kanak-kanak Kecamatan Koto Tangah Kota Padang. Pola komunikasi orangtua memiliki hubungan terhadap perkembangan berbicara anak di Taman Kanak-kanak Kecamatan Koto Tangah.

Menurut Vygotsky dalam Nurhafizah (2012), berbicara atau berkomunikasi adalah cara-cara penyampaian informasi secara lisan dengan menggunakan bahasa sebagai sarana komunikasi yang pengembangannya berdasarkan daya imajinasi manusia. Sedangkan menurut Fries, berbicara atau berkomunikasi merupakan tahap awal atau permulaan seseorang untuk menguasai suatu bahasa.

Nurhafizah (2012) berpendapat bahwa banyak hal yang dapat mempengaruhi komunikasi, yaitu: 1) latar belakang budaya, interpretasi suatu pesan akan terbentuk dari pola pikir seseorang melalui kebiasaannya; 2) ikatan individu dengn kelompok atau grup; 3) harapan; 4) pendidikan, semakin tinggi pendidikan akan semakin kompleks sudut pandang dalam menanggapi isi pesan yang disampaikan; 5) situasi.

Situasi yang dimaksud oleh Nurhafizah (2012) yaitu 1) faktor ekologis (iklim atau kondisi alam); 2) faktor rancangan dan arsitektural atau penataan ruangan; 3) faktor temporal seperti keadaan emosi; 4) suasana prilaku seperti cara berpakaian dan cara berbicara; 5) teknologi; 6) faktor sosial mencakup sistem peran, struktur sosial, dan karakteristik sosial individu; 7) lingkungan psikososial yaitu persepsi seseorang terhadap lingkungannya; 8) stmuli yang mendorong dan memperteguh perilaku.

Menurut Hendri (2013) mengatakan bahwa ada tiga pola komunikasi, yaitu : 1) Pola Komunikasi Authotarian (bersikap bermusuhan), dalam pola hubungan ini sikap acceptance orangtua rendah, namun kontrolnya tinggi, suka menghukum secara fisik, bersikap mengkomando (mengharuskan / memeritah anak untuk melakukan sesuatu tanpa kompromi), bersikap kaku (keras), cenderung emosional dan bersikap menolak; 2) Pola Komunikasi Permissive (berprilaku bebas), dalam hal ini sikap acceptance orangtua tinggi, namun kontrolnya rendah, memberi kebebasan 
kepada anak untuk menyatakan dorongan atau keinginannya. Sedang anak bersikap impulsif serta agresif, kurang memiliki rasa percaya diri, suka mendominasi, tidak jelas arah hidupnya dan prestasinya rendah. 3) Pola Komunikasi Authoritative, dalam hal ini acceptance orangtua dan kontrolnya tinggi, bersikap responsif terhadap kebutuhan anak, mendorong anak untuk menyatakan pendapat atau pertanyaan, memberi penjelasan tentang dampak perbuatan yang baik dan buruk. Suatu proses komunikasi dapat berjalan dengan baik jika antara komunikator dan komunikan ada rasa percaya, terbuka dan sportif untuk saling menerima satu sama lain.

Hasil penelitian di Taman Kanak - kanak Kecamatan koto tangah kota padang mengenai perkembangan berbicara anak didapatkan hasil Statistik Deskripsi Data Penelitian yang menerangkan bahwa semua data valid (terbaca dengan baik), dan tidak ada data yang missing (hilang). Nilai dari data standar deviasi menunjukan kheheterogenan data yang diteliti, hal ini sesuai dengan penelitian yang peneliti teliti yaitu Hubungan Pola Komunikasi Orangtua Dengan Perkembangan Berbicara Anak. Besarnya angka variansi menunjukan keberagaman instrumen yang dibuat sehingga data atau variabel penelitian dapat dinilai validitasnya dan layak diikutsertakan dalam instrumen penelitian. Dari hasil penelitian juga ditemukan skor jawaban terendah dan skor jawaban tertinggi dari angket Pola Komunikasi Orangtua dan Perkembangan Berbicara Anak berdasarkan jawaban angket yang telah diisi oleh responden. Dari distribusi skor tersebut didapat rata-rata (mean), skor tengah (median), sehingga juga didapat jumlah nilai (sum) dari data penelitian.

Dari penelitian yang telah peneliti lakukan, disini peneliti melihat bahwa orangtua yang ada di Taman Kanak kanak Kecamatan Koto Tangah Kota Padang lebih menggunakan pola komunikasi Authoritative dibandingkan dengan pola komunikasi authotarian dan permissive, yang mana pada pola komunikasi authoritative ini orangtua lebih bersikap responsif terhadap anak dan selalu mendorong anak untuk menyatakan pendapatnya dan orangtua juga memberikan penjelasan tentang dampak perbuatan baik dan buruk terhadap anak. Hal ini terbukti dari hasil penelitian pada indikator authotarian ditemukan hasil bahwa kebanyakan orangtua tidak pernah mencubit anaknya, kemudian orangtua jarang bersikap keras terhadap anaknya. Orangtua jarang memberikan batasan terhadap anak. Dalam menentukan keputusan, orangtua jarang membatasi anaknya dan kebanyakan orangtua sering mengekang anak.

Pada indikator permissive ditemukan orangtua terkadang menuruti semua keinginan anaknya, kemudian orangtua sering menerima terhadap keterbukaan anak. Orangtua tidak pernah mengontrol anak dan membiarkan anak bebas melakukan apa saja, ketika anak melakukan kesalahan orangtua jarang menghukumnya, orangtua jarang membuat anak merasa bahwa sebenarnya orangtua selalu memberikan perhatian yang lebih pada anaknya.

Pada indikator authoritative ditemukan hasil orangtua selalu menghargai apa yang dikerjakan oleh anaknya, mendengarkan setiap keluhan anaknya, memberi kebebasan sesuai kesepakatan yang telah dibuat bersama dan menghargai kemandirian yang dilakukan anak. selain itu orangtua juga selalu mempertimbangkan terlebih dahulu keputusan yang dibuat orangtua dengan anaknya.

Selanjutnya peneliti menemukan data tentang perkembangan berbicara anak dari guru kelas yang ada di tiga taman kanak - kanak koto tangah kota padang, bahwa sudah banyak anak yang memiliki kosakata yang mudah dimengerti. Terkadang bahasa yang diungkapkan anak mudah dimengerti walaupun sebagian anak bahasanya masih kurang dimengerti oleh guru. Ketika proses belajar, anak-anak menunjukan rasa keinginan untuk belajar, tetapi terkadang ketika diberikan pertanyaan oleh guru anak hanya mengangguk dan menggelengkan kepala untuk menjawab. Terkadang anak hanya terdiam ketika memasuki lingkungan yang baru tetapi ketika anak sudah mengenal lingkungan tersebut banyak anak yang sudah berani mengungkapkan pendapatnya dan berani untuk mengajukan pertanyaan. Dan di taman kanak-kanak sudah banyak anak yang bisa membedakan huruf dengan benar.

Hasil penelitian ini sesuai dengan teori yang telah dikemukakan oleh para ahli komunikasi dan bahasa. Menurut Harris dalam Otto (2015) mengatakan bahwa dalam berkomunikasi anak didorong untuk meniru ucapan orang lain (terutama orangtuanya). Sehingga ucapan orangtua dapat ditiru oleh anak. Sejalan dengan itu, menurut Djamarah (2014) mengatakan bahwa kemampuan anak mengucapkan kata-kata merupakan hasil belajar melalui imitasi (peniruan) terhadap suara-suara yang didengar anak dari orang lain terutama orangtuanya sendiri. Oleh karena itu bagaimana orangtua berkomunikasi dengan anak dapat ditiru oleh anak sehingga sangat berpengaruh sekali terhadap perkembangan berbicara anak. Menurut Vygotsky dalam Nurhafizah (2012), berbicara atau berkomunikasi adalah cara-cara penyampaian informasi secara lisan dengan menggunakan bahasa sebagai sarana 
komunikasi yang pengembangannya berdasarkan daya imajinasi manusia. Sedangkan menurut Fries, berbicara atau berkomunikasi merupakan tahap awal atau permulaan seseorang untuk menguasai suatu bahasa.

Hasil penelitian tersebut, pola komunikasi orangtua memiliki hubungan dengan perkembangan berbicara anak, terutama pola komunikasi Authoritative. Pola Komunikasi Authoritative ini sangat mempunyai peran penting terhadap perkembangan berbicara anak, yang mana pada pola ini orangtua lebih mendengarkan setiap keluhan anak dan orangtua selalu melakukan kontrolan terhadap anak. Apabila orangtua berkomunikasi sesuai dengan pola komunikasi orangtua yang baik maka perkembangan berbicara anak juga dapat berkembang dengan baik. Namun apabila orangtua berkomunikasi tidak sesuai dengan aspek pola komunikasi orangtua maka perkembangan berbicara anak akan terhambat. Misalkan orangtua menerapkan pola komunikasi yang Authotarian, yang mana pada pola komunikasi ini orangtua mempunyai kontrolan yang tinggi terhadap anak, namun suka menghukum secara fisik, jika pola komunikasi ini diterapkan oleh orangtua maka perkembangan berbicara anak akan terhambat, karena sifat orangtua yang terlalu keras terhadap anak dan dapat mengakibatkan anak trauma untuk berbicara sehingga dapat dikatakan pola ini dapat menyebabkan terhambatnya perkembangan berbicara anak. oleh karena itu orangtua harus selalu menerapkan pola komunikasi yang Authoritative agar perkembangan berbicara anak dapat berkembang dengan baik, sehingga dapat ikatakan bahwa penelitian ini membuktikan bahwa pola komunikasi orangtua memiliki hubungan dengan perkembangan berbicara anak.

\section{KESIMPULAN}

Berdasarkan hasil penelitian dan pembahasan sebelumnya bahwa terdapat hubungan pola komunikasi orangtua terhadap perkembangan berbicara anak di Taman Kanak - kanak kecamatan koto tangah kota padang dengan sig> 0,05 dan sumbangan yang diberikan oleh pola komunikasi orangtua 43,4\% artinya bahwa pola komunikasi orangtua memiliki hubungan yang cukup terhadap perkembangan berbicara anak. Dapat disimpulkan bahwa pola komunikasi orangtua memiliki hubungan terhadap perkembangan berbicara anak. Apabila orangtua menerapkan pola komunikasi dengan tahap - tahap perkembangan berbicara anak maka perkembangan berbicara anak akan dapat berkembang dengan baik.

\section{DAFTAR RUJUKAN}

Ahmad, Susanto. (2012). Perkembangan Anak Usia Dini. Jakarta: Kencana

Arikunto, Suharsimi. (2013). Dasar-Dasar Evaluasi Pendidikan. Jakarta: Bumi Aksara

Ferliana \& Agustina. (2015). Meningkatkan Kemampuan Berkomunikasi Anak Aktif Pada Anak Usia Dini. Jakarta: Luxima

Dadan, Suryana. (2013). Pendidikan Anak Usia Dini (Teori dan Praktik Pembelajaran). Padang : UNP Press.

Djamarah, Syaiful Bachri. (2014). Pola Asuh Orang Tua dan Komunikasi dalam Keluarga. Jakarta: Prenada

Hendri, Gunawan. (2013). Jenis Pola Komunikasi Orangtua Dengan Anak Perokok Aktif. Jurnal.

Nurhafizah, N. (2018). Bimbingan Awal Kewirausahaan pada Anak Usia Dini. Jurnal Konseling dan Pendidikan, 6 (2).

Nurhafizah. 2015. Pengembangan Pembelajaran Sains Pada Anak Usia Dini. Scientific Forum Faculty of Education Departement of Science Education FIP

Nurhafizah, N. (2018). Pelatihan Pembuatan Media Pembelajaran Anak Usia Dini menggunakan Bahan Sisa. Early Childhood: Jurnal Pendidikan, 2(2b), 44-53.

Nurhafizah, N. (2017). Strategi Pengembangan Kemampuan Sains Anak Taman Kanak-Kanak di Koto Tangah Padang. Pedagogi, 3(3b).

Nurhafizah. (2012). Kemampuan Berkomunikasi Sebagai Salah Satu Pilar Profesionalisme Guru Dalam Membimbing Anak Usia Dini. Proseding Temu Ilmiah FIP JIP (hal: 457-468). FIP UPI, Bandung

Nurhafizah. (2012). Relatiohip between the Intensity Parents Guidance to Early Math in Kingderganten. Proseding

SPPG Malindo. IPG Kampus Ilmu Khas:Kuala Lumpur Malaysia.

Nurhafizah. (2014). Penanaman Perilaku Disiplin pada Anak sejak Usia Dini. Proseding SEMNAS PGPAUD UNP. PGPAUD FIP UNP: Padang

Otto, Beverly. (2015). Perkembangan Bahasa pada Anak Usia Dini. Jakarta: Kencana 
Suyadi. (2014). Teori Pembelajaran Anak Usia Dini. Bandung: PT Remaja Rosdakarya.

Zulkifli, (2005). Psikologi Perkembangan. Bandung. PT. Remaja Rosda Karya. 